\title{
RESTRUCTURING OF LOANS - NECESSITY AND EFFECTS IN ROMANIAN BANKING ACTIVITY
}

\section{Ionela-Gabriela Matei}

Finance Department, Doctoral School of Economics and Business Administration, Alexandru loan Cuza University, Iași, Romania

matei.ionelagabriela@gmail.com

\begin{abstract}
Banks will use specific tools to develop and compare alternative scenarios to determine what the opportunities to restructure a loan are, and to identify the most appropriate bargaining levers. Restructuring activity involves early identification of the problem and empowering teams consisting of bank specialists to solve the magnitude of the existing intervention. After analysing the unfavourable situation of the customer they perform the necessary steps to implement and monitor the restructuring solution. Also, banks are following and evaluating the risks associated with the restructuring of loans to cover up or avoid the occurrence of effects that will degrade the good functioning of things. Customers should be informed about the restructuring process to see what kind of measures can be taken to improve their financial situation. They can solve their financial difficulties by changing the monthly payments and their business activities. The issues that affect the customers are the increased payment amounts and the time when those payments have to be made. In case of insolvency, the banks resort to the judicial reorganization of the clients' activity, in order to avoid enforcement or bankruptcy of the company, which will create negative repercussions on the functioning of the bank's financial system but also on the image created by this. This paper aims to analyse the implications of the restructuring of loans for banks and customers. The analysis has been conducted by using an econometric study based on annual data of banks active in Romania.
\end{abstract}

Keywords: restructuring procedure, judicial reorganization, performance, insolvency

JEL Classification: D81, E43, G21

\section{Introduction}

Restructuring is an ample process being carried out by a bank if a private or public company is faced with cash flow problems, a process that involves debt renegotiation in order to restore liquidity.

When we talk about associated costs of restructuring a credit, we are taking into consideration the time and effort needed to negotiate with creditors (banks), suppliers and tax authorities. Also, restructuring involves either lowering overdue rates and extending payment periods, or reducing credit-related costs.

Currently, under the influence of the economic situation in Romania, banks evaluate the behaviour and activity of the customers regarding the restructuring (the economic and financial situation is analysed and also, the level of arrears accumulated by them). The Bank also evaluates and analyses the customers' ability to pay, taking into account their ongoing contracts and the cash flow level, and reports on market developments and business areas in which customers operate.

In the case of restructuring, borrowers are required to prove the fortuitous revenue reduction from the initial moment when the credit was contracted and to present to the bank the 
causes that led to the emergence of those difficulties that prevent them from repaying the loan.

Restructuring can also be applied to non-performing loans, which are recovered by starting existing court procedures. This can have an impediment on the value of the collateral. This type of loan can be solved by implementing the restructuring process, in which case the borrower must fulfil the conditions imposed by the bank's lending policy or by restructuring the credit under the control of the bailiff or the bank executor.

Restructuring is an essential step in using relaxation reimbursement schemes, a relationship that involves transparency and honesty between the two parties in a credit agreement.

\section{Primary Considerations of Restructuring}

The restructuring is based on a number of considerations, including: evaluating the financial behaviour of the client and his collaboration with the bank, the client's compliance with the term of the ongoing credit agreements, analysing the client's annual financial statements, adjusting the cash flow by correlating with market evolutions and trends followed by the company's field of activity, framing with the eligibility criteria imposed by the bank, the customer's ability to respect the repayment schedule and identifying its ability to recover payments recorded over a period of time. Furthermore, banks are focused on the most profitable activities, avoiding high-risk lending conditions. (Busuioc Witowschi, 2012)

In order to implement the loan restructuring, the bank has the obligation to identify those customers who face difficulties in the business, establish the adequate solutions for the restructuring, analyse the financial situation of the client and finally approve the restructuring.

\subsection{Restructuring - Alternative or Necessity for Bank Customers}

Restructuring in essence is a multitude of operations designed to support customers in overcoming certain financial difficulties that they encounter during the course of the credit agreements related to the activity. In order to better understand this process, it is being analysed the problem in the first stage, which is why restructuring is being used (Bank for International Settlements, 1999), and we are talking about: a decrease in the borrower's income and his or her family, the occurrence of medical, partial or total disability issues of the borrower leading to a discontinuation of the previously performing business, change of company management and other issues affecting the regular repayment of the loan (exchange rate, high indebtedness etc.). In this context, the restructuring may provide for changes in the maturity date, interest rate or any contractual clauses contained in the contracts concluded by the banks with the clients. (Godîncă-Herlea, 2013)

The analysis performed by the bank is summed up on the revenue level at the time the loans are granted, their evolution during crediting, the current level of revenues and the changes in the real estate market for the buildings with which the contracted loan was guaranteed.

The second step in this process is the renegotiation of contracts. In this case, we talk about two possibilities: the customers' anticipation of an event that will affect the revenue generated by the activity or the detection of the already existing problem. Therefore, the client will contact the bank by arranging a meeting with one of the financial consultants, and then the financial problems of the company are reported. In the end the customer will complete the related documentation. Implementation of the restructuring decision is done by signing an Additional Act to the credit contract and in some cases to the mortgage contract. Also, the customer will make a restructuring request, which he addresses to the bank having as references: the factors that led to the problem, its evolution and the plans for future income. In addition to the restructuring request, the client will provide the bank with these documents: the decision to cessation the employment contract, the decision to decrease 
income, medical documents, identity documents, consultation agreements in the databases and evaluation reports for all real estate properties under the loan guarantee.

In this case, the bank seeks reimbursement solutions that benefit the client, solutions that relate to maintaining an acceptable level of outstanding balance, as well as credit risks and default risks. Regardless of what restructuring method (Celano, 2009) is chosen, the bank doesn't consider the eligibility conditions from the time when the loan was granted. This is why it is important to search the best solution to help the customer overcome those unfavorable situations that stop him in his pay rates in a useful time. For these reasons, the bank provides information to the client about the risks of increasing the credit balance by capitalizing outstanding amounts and unpaid interest.

In conclusion, the bank has a fundamental role of supporting the customer in the unfavorable situations, but also advising him on how to repay the loans, which is why it identifies the optimal solutions for maintaining contractual relationships, avoiding the accelerated recovery credit through judicial measures.

\subsection{The Effects on the Credit Restructuring Process}

Restructuring operations refer to a series of solutions (Chorafas, 2006), including partial or total gratification for one or more components of the loan - a period that varies between 6-12 months as the case may be, the partial or total capitalization of debts recorded on a the loan maturity extension to decrease the volume of monthly client instalments, the modification of a revolving credit facility into a monthly credit facility, the refinancing of the remaining loan to be repaid, changing the currency of the loan, the reduction of the loan interest and other discounts. Also, the number of restructuring operations differs from case to case and these are analysed individually.

In essence, restructuring implies a quick implementation flow, improves the financial situation of the companies concerned, eliminates the cost of overdue payments and avoids enforcement and insolvency. In this case, debt restructuring and loan negotiation done by the bank is based on a previous analysis and projected cash flows of the company. (Popescu, 2009)

Being a way to overcome the borrower's financial difficulties, restructuring generates a number of positive benefits, being different from case-to-case, therefore: identifying new outlets, producing cost-sales efficiency, diversifying and intensifying those activities existing inside of the company that earns high profits, obliges associates or shareholders to act in order to increase profits and achieve a high performance management. (ABC Training Consulting S.R.L., 2009)

The first criterion which a customer needs to consider for applying to credit restructuring refers to the age of the credit, which changes the credit conditions as a whole radically after restructuring due to the costs incurred, the bureaucracy, the amounts accessed and the approval time. The second aspect considers the structure of loans (Golin, 2013), which leads to accumulation of credits and facilities assigned to them under one loan at a below the average of the interest of the separate loans. Finally, credit costs are constantly changing due to market fluctuations occurred. (KIWI Finance SRL, 2015)

A special effect of the restructuring is represented by the conversion of debt into equity, an effect that avoids the repo. Conversion is a method commonly used by banks, because it can benefit the debtor in terms of indebtedness, the financial performance class, the possibility of contracting new loans and relieving the repayment of loans. In Romanian law ${ }^{* * *}$ Law 85/2014 \& Law 31/1990, 2017), this operation will increase the interest in debt conversion for companies and banks, being used for all existing business fields.

Regarding the benefits of this type of process, they relate to reducing or eliminating interest payments and increasing the financial performance of the debtor, as well as obtaining a shareholding by the lender at a lower price than the price when the company was profitable, 
and the opportunity to participate in company management and change of business strategy.

This procedure also presents a number of disadvantages for both sides of a credit agreement. A first aspect is where the lender has no experience or knows only a little bit about the borrower's business, which will lead to poor business performance. And about the creditor (Myers, 2002), he can be held liable if he proves that he is responsible for bringing the company into insolvency or even bankruptcy and that he will not receive his annual dividend due to the unfavourable performance recorded by the debtor.

\subsection{Extrajudicial restructuring of mortgage-backed loans}

The restructuring operation is a less costly alternative, being done with the aim of avoiding enforcement or bankruptcy.

Debt mediation was born after the international economic crisis in 2008 and is designed to help small enterprises and private persons by ending or avoiding litigation who lead to enforcement and bankruptcy. (Altman, 2010)

Among the regularly used methods of restructuring, there are also some conventional methods, including: cession of receivables, subrogation and novation. Using the cession of receivables $\left({ }^{* *}\right.$ Law $\left.287 / 2009,2017\right)$ requires the transfer of the receivables right by onerous title (including guarantees) from the assignor (the bank) to the assignee (private and legal person). Also, the subrogation ${ }^{* * *}$ Law 287/2009, 2017) involves the transfer of obligations recorded into a legal report, the transfer consisting in the replacement of the creditor (bank) by a third party paying the debtor's debt, which assigns to the third party all the rights of the creditor (including guarantees). About novation ( ${ }^{* * *}$ Law 287/2009, 2017), this is a convention whereby the parties to a legal report extinguish an existence obligation by generating a new one by changing the object of the contract or by replacing the debtor or the creditor.

Changing contractual terms of a loan granted initially by a client may be denied by the bank if there is no legal basis (Simon, 2000) and the borrower doesn't prove the unfavourable status or insolvency they are in, which would prejudice the interests of one part or even both parts. Between the bank and the client must be an equality report that suggests the fulfilment of minimum requirements by both the bank and the client, requirements which must be observed under the legislation existing in Romania at present.

Extrajudicial procedure for restructuring of loans (Ministry of Public Finance, 2010) (Garrido, 2012) is based on a series of principles that apply only to borrowers with financial difficulties likely to affect or lead to the impossibility of enforcing the obligations under the mortgage credit agreement. A first principle is that the debtor contacts the creditor as soon as possible to engage in a discussion about the financial issues that block payment instalments but also to find a series of solutions that benefit the common interest of the parties. As part of the second principle, the creditor must clearly and concisely present to the debtor the full status of the obligations under the credit agreement and the debtor must provide the bank with all necessary information to show the source of the issues, including supporting documents about income and financial assets. Also, the restructuring of mortgage-backed loans is a concession and not a right, because of the willingness of both parties. Therefore, the negotiations between the creditor and the debtor must be in good faith, based on a clear and transparent communication regarding all the relevant aspects of the contract. Both parties are considering the best solutions for restructuring of loans, before applying any measures of enforcement of the mortgage or other guarantees and make all procedures to implement them. 


\section{Implications of Loan Restructuring in Romania during the Post-Crisis Economic Recovery}

In Romania, credit restructuring has been rising in recent years due to the high non-performing loans recorded by banks' customers, due to the poor performance recorded by the clients in their business. Thus, given the intensification of the struggle for a higher market share, the risk of financing several non-viable projects has increased, due to the relaxation of credit conditions. (Minescu, 2013) Risks related to credit restructuring are based on a series of trigger factors, which require banks to pay attention to ongoing loans and borrowing behaviour.

To highlight the impact of loan restructuring in Romania, I realized an econometric study based on 15 banks, analysing a period of economic recovery (2010-2016). The data contained in this sample has been extracted from the annual financial reports of the top banks according to the turnover present in Romania, their choice and the determination of the large number of variables was determined by the fact that the level of debts can be influenced by a multitude of factors, and a minimal number of them would not have a significant relevance in the study. A short description of the variables used in the regression can be found in table 1 .

We want to test the following null hypothesis:

$\mathrm{H}_{0}$ : Variables related to banking activity have no statistically significant impact on the level of indebtedness

If the null hypothesis is rejected, this means that certain variables related to banking activity have an impact on the level of indebtedness, a variable stating the amount of non-performing loans. This can both be positive and negative, respectively increasing or decreasing the level of indebtedness of banks.

Table 1: Description of the variables

\begin{tabular}{|c|c|}
\hline Variable & Definition \\
\hline $\begin{array}{l}\text { Level of } \\
\text { Indebtedness }\end{array}$ & $\begin{array}{l}\text { This indicator shows how much is due the bank in relation with regards } \\
\text { to the sum of shareholder equity and borrowed capital. }\end{array}$ \\
\hline GDP & $\begin{array}{l}\text { Reflects the sum of the market value of all end-use services produced in } \\
\text { all branches of the economy in one year of Romania. }\end{array}$ \\
\hline Development & $\begin{array}{l}\text { Set of quantitative, structural and qualitative transformations in the } \\
\text { economy, scientific research etc. }\end{array}$ \\
\hline $\begin{array}{l}\text { Herfindahl-Hirsc } \\
\text { hman Index }\end{array}$ & $\begin{array}{l}\text { This index measures the degree of concentration of the market. The } \\
\text { market share of each bank competing in a market is squared, and then } \\
\text { the resulting figures are summed up. }\end{array}$ \\
\hline Inflation & $\begin{array}{l}\text { Reflects the general rise in prices and the simultaneous decrease in the } \\
\text { purchasing power of the national currency RON. }\end{array}$ \\
\hline Net Income & Net income after taxation calculated in RON. \\
\hline Total Capital & $\begin{array}{l}\text { The bank's capital consists of own resources and resources } \\
\text { from the economy (borrowed from individuals, legal persons }\end{array}$ \\
\hline Total Assets & Reflects all the financial resources held by a bank. \\
\hline $\begin{array}{l}\text { Unemployment } \\
\text { Rate }\end{array}$ & $\begin{array}{l}\text { The total number of people who remain without a country-related job as } \\
\text { a percentage. }\end{array}$ \\
\hline ROE & $\begin{array}{l}\text { Represent the amount of a banks net income as a percentage over } \\
\text { shareholders equity. }\end{array}$ \\
\hline ROA & This indicator shows how profitable a bank is relative to its total assets. \\
\hline
\end{tabular}


The identification of the linear regression model was achieved by checking the normality and non-correlation conditions at the level of the banks in Romania, a process considered useful in the context of the negative effects caused by the global financial crisis.

Appendix A highlights the main statistical indicators of the variables considered as a development of the values from the table with the estimation equation; basically, these indicators are calculated for each variable, with more details being noticed which are significant or not from a statistical perspective.

The required results were obtained by applying the Panel Least Squares method with 105 observations that had as source the database discussed above and are presented in table 2 , which can be found below:

Table 2: Level of indebtedness

\begin{tabular}{|l|l|l|l|}
\hline Variable & Coefficient & t-Statistic & Prob. \\
\hline GDP & $9.61 \mathrm{E}-14$ & 0.199823 & 0.8421 \\
& $(4.81 \mathrm{E}-13)$ & & \\
\hline Development & 1.903 & 0.992224 & 0.3236 \\
& $(1.918)$ & -0.264151 & 0.7922 \\
\hline Herfindahl-Hirschman Index & -0.000106 & & \\
\hline Inflation & $(0.000401)$ & -0.109198 & 0.9133 \\
\hline Net Income & -0.152 & & \\
& $(1.393)$ & -0.061634 & 0.9510 \\
\hline Total Capital & $-1.67 \mathrm{E}-12$ & & \\
& $(2.72 \mathrm{E}-11)$ & 0.620633 & \\
\hline Total Assets & $1.88 \mathrm{E}-11$ & & 0.5339 \\
& $(3.03 \mathrm{E}-11)$ & -0.624409 & \\
\hline Unemployment Rate & $-1.98 \mathrm{E}-12$ & & 0.7713 \\
& $(3.17 \mathrm{E}-12)$ & 0.291551 & \\
\hline ROE & 1.432 & & \\
& $(4.911)$ & 2.248180 & \\
\hline ROA & 1.346 & -1.993880 & 0.0491 \\
\hline C & $(0.599)$ & 0.693424 & 0.4898 \\
\hline R-Squared & -11.006 & & \\
\hline
\end{tabular}

This table shows the results of the ordinary least squares panel regression with the level of indebtedness as the dependent variable. Standard errors are reported in parentheses.

*** Statistical significance at a 0.01 level

** Statistical significance at a 0.05 level

* Statistical significance at a 0.10 level

Source: Author's calculations based on data extracted from annual bank reports

The dependent variable is the degree of indebtedness, and as independent variables we have chosen the degree of development, Herfindhal Hirschman Index $(\mathrm{HHI})$, inflation rate, bank net income, total bank capital, total assets, unemployment rate, the average ROE and the average ROA. Based on the value obtained in the determination ratio, $\mathrm{R}$ Squared, it results that only $17.63 \%$ of the dependent variable is explained or determined by the variation of the independent variables.

Both the return on equity and the return on assets have a statistically significant impact on the level of indebtedness, both at the 0.05 level. This means we reject the null hypothesis, and we can conclude that these two specific variables, in fact, have an impact on the level of 
indebtedness. The ROE has a positive coefficient of 1.346 , while the ROA has a negative impact with a value of -11.006 .

If we refer to the mathematical formula of this regression model, it takes the form of:

LEVEL_OF_INDEBTEDNESS $=\mathrm{C}(1)^{*} \mathrm{GDP}+\mathrm{C}(2){ }^{*}$ DEVELOPMENT +

$\mathrm{C}(3)^{*} \mathrm{HE}$ EFFINDAHL_HIRSCHMAN_INDEX + C(4)*INFLATION + C (5)*NET_INCOME +

$\mathrm{C}(6)^{\star}$ TOTAL_CAPITAL $+\mathrm{C}(7) *$ TOTAL_ASSETS + C(8)*UNEMPLOYMENT_RATE +

$\mathrm{C}(9)^{*}{ }_{-} \mathrm{ROE}+\mathrm{C}(10)^{*}{ }_{-} \mathrm{ROA}+\mathrm{C}(11)$

Substituted Coefficients:

LEVEL_OF_INDEBTEDNESS $=9.61454100608 \mathrm{e}-$

$14^{*} \mathrm{GDP}+1 . \overline{9} 0324398958^{\star}$ DEVELOPMENT0.000105845758677*HERFINDAHL_HIRSCH

MAN_INDEX - 0.152086167378*INFLATION - 1.67455575792e-12*NET_INCOME +

$1.88167486122 \mathrm{e}-11^{*}$ TOTAL_CAPITAL - 1.97764668227e-12*TOTAL_ASSSETS +

$1.43175459078 *$ UNEMPLOYMENT_RATE $+1.34557966612^{*}$ ROE -

$11.006393591^{*}$ ROA + 0.503222110435,

where the terms $C(1)-C(11)$ are the coefficients of the regression equation, along with the random variable.

The confidence intervals for the coefficients, analyzed in appendix $B$, are summarized in the following figure:
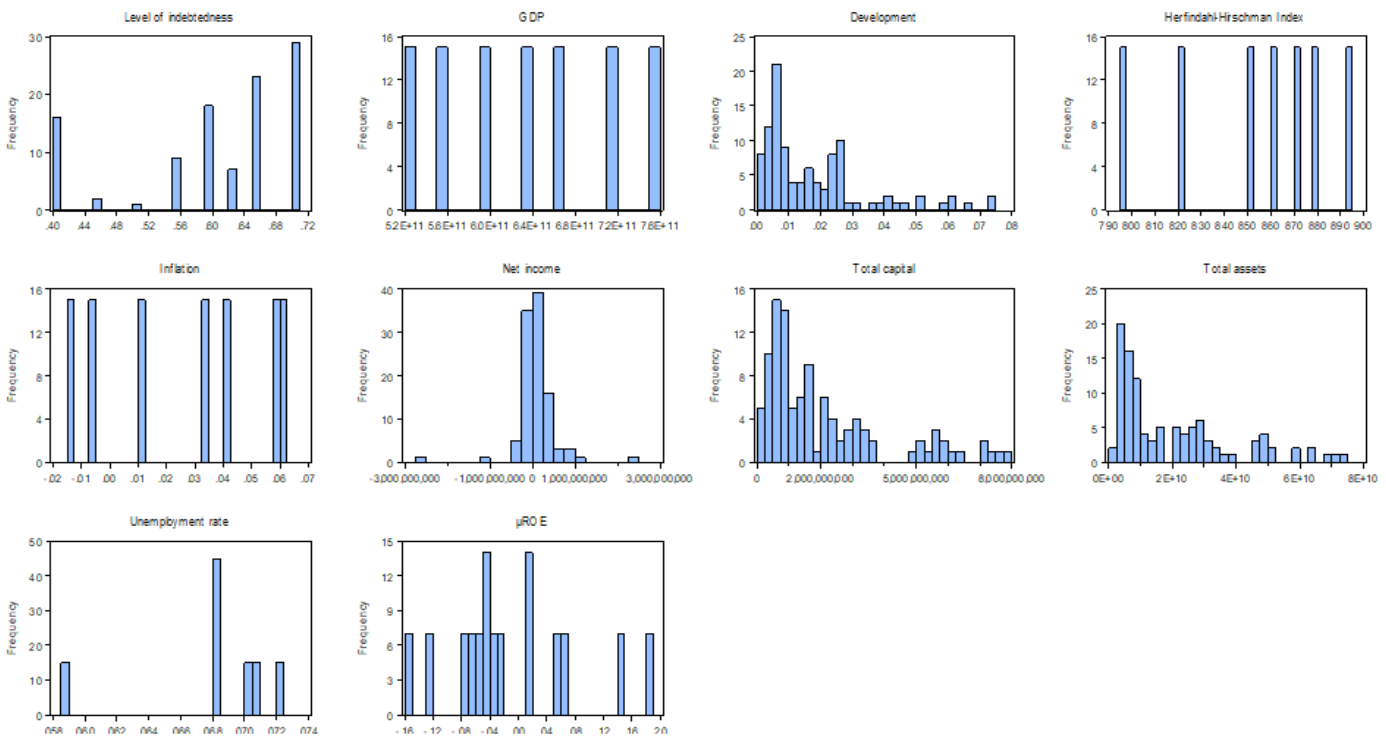

Figure 1: Distribution of dependent and independent variables

Source: Author's calculations based on data extracted from annual bank reports

The graphs show that most of the variables have a normal distribution. 

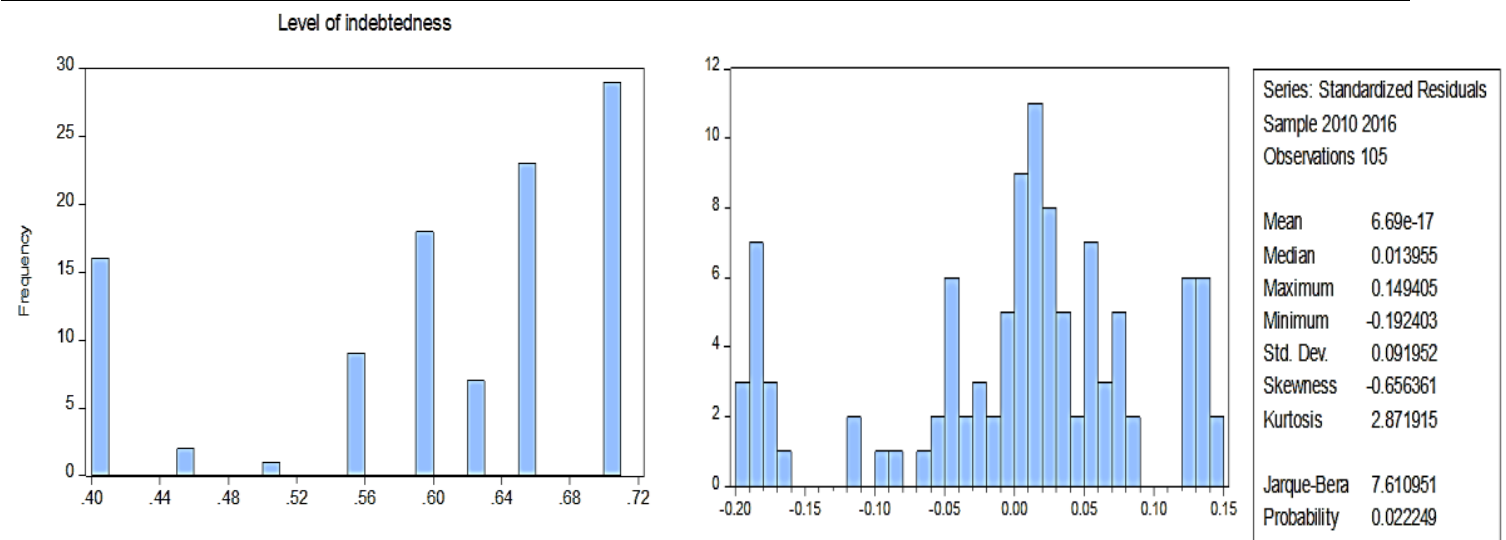

Figure 2: The Histogram results

Source: Author's calculations based on data extracted from annual bank reports

According to the statistical results, the histogram attributed to the group of variables analyzed from the visual point of view reveals an abnormal distribution. This distribution can be explained by the skewness value of -0.656361 that is different from 0 , which suggests distribution abnormality. Also, the Kurtosis value of 2.871915 does not exceed the threshold of 3 , resulting in this case a platykurtic distribution. The standard deviation recorded at 0.091952 shows a distribution not too far from normality.

Following the White and Breusch-Pagan-Godfrey tests to correct heteroskedasticity, the results are synthesized in table 3, which can be found below:

Table 3: White Test for heteroskedasticity correction

\begin{tabular}{|l|l|l|l|l|}
\hline Variable & Coefficient & Std. Error & t-Statistic & Prob. \\
\hline GDP & $9.61 \mathrm{E}-14$ & $1.05 \mathrm{E}-13$ & 0.912493 & 0.3638 \\
\hline Development & 1.903244 & 1.112652 & 1.710547 & 0.0905 \\
\hline Herfindahl-Hirschman Index & -0.000106 & $6.12 \mathrm{E}-05$ & -1.730555 & 0.0868 \\
\hline Inflation & -0.152086 & 0.143780 & -1.057771 & 0.2929 \\
\hline Net Income & $-1.67 \mathrm{E}-12$ & $1.01 \mathrm{E}-11$ & -0.165107 & 0.8692 \\
\hline Total Capital & $1.88 \mathrm{E}-11$ & $2.07 \mathrm{E}-11$ & 0.910963 & 0.3646 \\
\hline Total Assets & $-1.98 \mathrm{E}-12$ & $1.43 \mathrm{E}-12$ & -1.379701 & 0.1710 \\
\hline Unemployment Rate & 1.431755 & 0.785497 & 1.822737 & 0.0715 \\
\hline ROE & 1.345580 & 0.338468 & 3.975500 & 0.0001 \\
\hline ROA & -11.00639 & 2.933081 & -3.752503 & 0.0003 \\
\hline C & 0.503222 & 0.152104 & 3.308406 & 0.0013 \\
\hline R-squared & 0.176347 & & \\
\hline
\end{tabular}

Source: Author's calculations based on data extracted from annual bank reports

After the White test, almost all the coefficients are statistically significant because the probability is below $0.2 \%$, the Durbin Watson value is 0.21 , which means that the equation is positively correlated, the value of $\mathrm{R} 2$ is 0.17 , suggesting that the independent variables explain $17 \%$ of the variance in the dependent variable.

According to the generated results, net income and inflation have a major impact on the degree of indebtedness, which is also normal given that they are important components in the application of loan restructuring as the last saving solution, and external factors are also included in the calculation. The average ROE and average ROA of each bank has a small impact. 
This equation has been selected because the Akaike and Schwarz criteria have the lowest value in the plurality of chosen equations.

Following the Granger Causality test, for which the results can be found in Appendix E, we can observe that any pair of variables taken into account is not affected by this test.

Therefore, the equation is correct and the null hypothesis is valid.

The residual values are illustrated below:

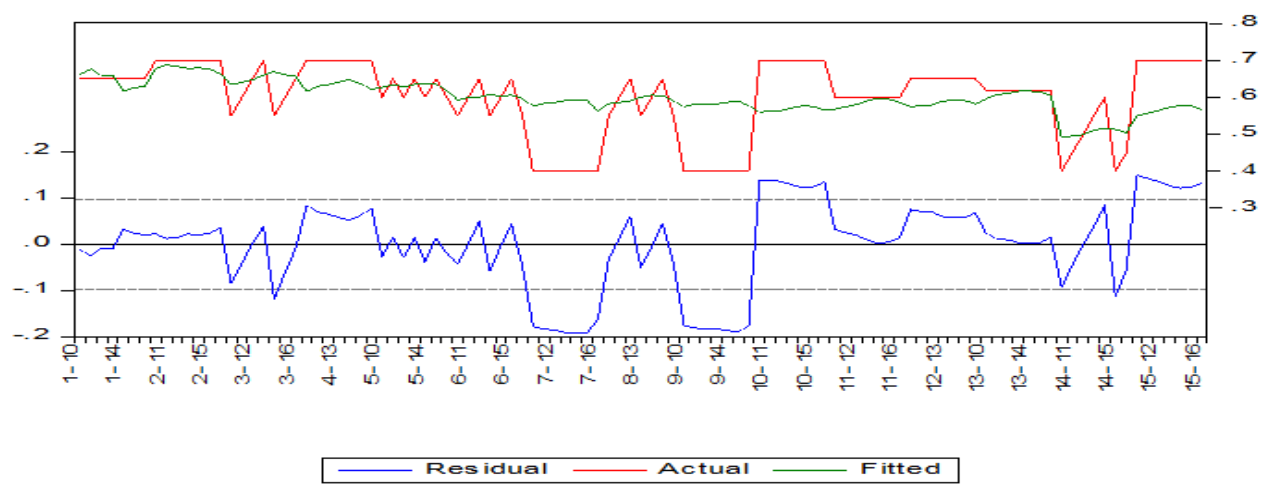

Figure 3: The residual values

Source: Author's calculations based on data extracted from annual bank reports

The interpretation of the estimated coefficients indicates that: (1) the number of customer debts may increase if inflation is high but at the same time the economic situation affects the client's financial situation; (2) the number of debts may decrease if the financial situation of the clients improve, which is influenced by the sustainability of economy at the micro-and macroeconomic level.

The covariance analysis of the variables involved in the analysis is shown in Appendix C, and we can observe the degree of covariance of the variables, which is positive. The probability is below 1 in most cases, the t-statistically and the correlation between them that is strongly positive. Also, in Appendix D, it can be noticed that the degree of correlation of the variables is strongly positive, the correlation between the same variable is 1 .

\section{Conclusions}

In these times, influenced by internal and external factors of the banking system and the economy, restructuring of loans appears as a saving solution for those who have difficulties in their repayment.

From previous studies on the example of the Romanian banking system, if more taxpayers would appeal to one of the measures or programs offered by the banks in the system, which can be understood by those who want to appeal to a loan restructuring, the NPL rate would not be so high in some banks. The urge to take these measures in case of a financial impasse is increasing, which is a satisfactory thing.

Each credit institutions presents a personalized restructuring program for legal entities that are unable to repay the credit, so the business that they have won't suffer. The same example applies to individuals so that they are not repossessed. Perhaps in some cases they have no other resources, and for this reason the banks must be tolerant and provide assistance if needed.

During the economic recovery in Romania, there was a difficult moment for some customers who applied to restructuring in ignorance of the cause, which caused them to experience high costs due to refusals given by banks. 
Credit restructuring is a solution from the bank in order not to completely compromise a client's financial situation. For this reason, clients of banks ask for the best solutions that could benefit them in regards to their outstanding loan. The increase in non-performing loans is due to inefficiencies in the economic situation of a borrower, but also due to the fact that banks have low-level credit conditions.

Appendices are available at http://ojbe.steconomiceuoradea.ro/ volume 3, special issue.

\section{References}

ABC Training Consulting S.R.L., 2009. Restructuring of bank loans - way to overcome the crisis.

Altman, E. I. H. E., 2010. Corporate Financial Distress and Bankruptcy, Third Edition. New Jersey: John Wiley \& Sons, Inc..

Bank for International Settlements, 1999. Bank restructuring in practice. BIS Policy Papers, No. 6,.

Busuioc Witowschi, I. R., 2012. The Impact of Basel III on Romanian Banking System. Ovidius University Annals, XII(1), p. 1292.

Celano, M. G. W., 2009. Method and system for financial counseling. United States: PU.S. Application Data, No. 12/080, p. 422.

Chorafas, D. N., 2006. Wealth Management - Private Banking, Investment Decisions and Structured Financial Products. In: Oxford: Elsevier Ltd., pp. 91-112, 209-227.

Garrido, J. M., 2012. Out-of-Court Debt Restructuring. Washington, D. C.: The World Bank. Godîncă-Herlea, V. C. A., 2013. Mechanisms of reorganization and their contractual expression. The Courier Judiciar, VI.

Golin, J. D. P., 2013. The Bank Credit Analysis Handbook. Singapore: John Wiley \& Sons Singapore Pte. Ltd., pp. 42-45, 58-60.

KIWI Finance SRL, 2015. Refinancing or restructuring? [Online] Available at:

http://www.kiwifinance.ro [accessed 30 January 2018].

Minescu, B. G., 2013. Credit channel and Budget Balance: Empirical evidence from the new Member States of the European Union. Theoretical and Applied Economics, XX(3),p. 19.

Ministry of Public Finance, 2010. Guide for extrajudicial restructuring of mortgage-backed loans.

Myers, S. C., 2002. Determinants of corporate borrowing. Journal of Financial Economics, 5, pp. 147-175.

Popescu, D., 2009. Company restructuring in transition economy of Romania. Concept, methodology and measurement. Bucharest, Bucharest Academy of Economic Studies, Simon, W. H., 2000. The Practice of Justice. A Theory of Lwyers Ethics. London, England: Harvard University Press.

***Law 287/2009, C. C., 2017. Art. 1573, Cession of receivables.

*** Law 287/2009, C. C., 2017. Art. 1593- Art. 1598, Subrogation.

*** Law 287/2009, C. C., 2017. Art. 1613, Effects of novation on solidary and prudent debtors.

${ }^{* * *}$ Law 85/2014 \& Law 31/1990, C. C., 2017. Procedures for insolvency prevention and insolvency, Company Law, s.l.: s.n.

\section{Bio-note}

Ionela-Gabriela Matei, PhD student in Finance at the Doctoral School of Economics and Business Administration of the "Alexandru Ioan Cuza" University in Iasi, Romania. She graduated in 2015 the Finance-Banking Specialty in the Bachelor's degree program, following in-depth (master) studies in Banking and Financial Markets. Ionela participated in the writing of numerous research projects which won in competitions at "Alexandru loan Cuza" University, as well as in other universities and institutions in Romania. 